\title{
Nitrogen deposition and soil nitrogen dynamics in subtropical evergreen broad-leaved stands along an age-sequence
}

\author{
H.F. Zhao, X.J.Yao, Q. Wang, Y.S. Chen, X.N. Xu* \\ Department of Forest Science, Anhui Agricultural University, Hefei 230036, China. Corresponding author: xnxu61@yahoo.com.cn
}

\begin{abstract}
In order to reveal the effects of nitrogen $(\mathrm{N})$ deposition on forest ecosystems, we investigated the soil $\mathrm{N}$ dynamics across a chronosequence of subtropical evergreen broad-leaved forest stands in eastern China for two years. Current atmospheric $\mathrm{N}$ deposition was $18 \mathrm{~kg} \mathrm{ha}^{-1}$ year ${ }^{-1}$. Nitrogen fluxes in throughfall varied from 17 to $23 \mathrm{~kg} \mathrm{ha}^{-1}$ year $^{-1}$ with an increasing trend with stand age. The total $\mathrm{N}$ fluxes ranged from 7.3 to $9.3 \mathrm{~kg} \mathrm{ha}^{-1}$ year ${ }^{-1}$ under the forest floor and from 1.2 to $2.5 \mathrm{~kg} \mathrm{ha}^{-1}$ year $^{-1}$ at $30-\mathrm{cm}$ soil depth with the high values in the older stand. The net mineralization potentials in the old stands ranged from 19 to $24 \mathrm{mg} \mathrm{kg}^{-1} \mathrm{month}^{-1}$, and were $30-55 \%$ higher than those in the young stands. The inorganic $\mathrm{N}$ concentration and flux at $30-\mathrm{cm}$ soil depth were significantly $(p<0.05)$ correlated with net mineralization potential. The potential $\mathrm{N}$ transformation rates were significantly $(p<0.05)$ correlated with soil $\mathrm{C} / \mathrm{N}$ ratio and $\mathrm{DON}$ while not with forest floor $\mathrm{C} / \mathrm{N}$ ratio. Input-output budget suggests that the forest at our site is a finer buffering system to $\mathrm{N}$ deposition and is far from $\mathrm{N}$ saturation.
\end{abstract}

Keywords: age-sequence; mineralization potential; nitrogen availability; nitrogen leaching; subtropical forest

\section{Introduction}

Soil nitrogen availability is a primary factor controlling forest productivity. The relationships between soil processes and nitrogen availability have been well documented (e.g. Gundersen et al., 1998; Corre et al., 2010). The atmospheric $\mathrm{N}$ deposition has greatly increased $\mathrm{N}$ inputs to many forests worldwide and resulted in soil N-saturation of some forests (Aber et al., 1989). Soil $\mathrm{N}$ status could cause a change in plant nutrient regime, which might result in a change in foliar lignin: $\mathrm{N}$ ratio, followed by a change in the $\mathrm{C}: \mathrm{N}$ ratio in the forest floor. Consequently, these changes would affect $\mathrm{N}$ mineralization and nitrification which could result in increasing soil $\mathrm{N}$ availability (Yamashita, et al., 2004) and in great potential for $\mathrm{N}$ export (Borken and Matzner, 2004; Zhang et al., 2010b).

The net rates of $\mathrm{N}$ mineralization and nitrification measured in situ and the laboratory incubations and the $\mathrm{N}$ concentration and $\mathrm{C} / \mathrm{N}$ ratio of forest floor have been widely used as key indicators of $\mathrm{N}$ status in forest ecosystems. These soil parameters correlated significantly with the net primary productivity in forest ecosystems (Yamashita et al., 2004). Researches along $\mathrm{N}$ deposition gradients in the USA and Europe 
revealed a negative correlation between the $\mathrm{C} / \mathrm{N}$ ratio in the organic horizon and $\mathrm{N}$ mineralization, nitrification, and leaching rates (Dise et al., 1998). The soil mineral $\mathrm{N}$ flux and net $\mathrm{N}$ mineralization rate has been proposed as an indicator for $\mathrm{NO}_{3}^{-}$leaching from forest soils (Perakis and Sinkhorn, 2011).

The rapid expansion of industry and intensive agriculture has amplified the $\mathrm{N}$ emissions into the environment in China. During the 1990 to 2000 period, the total NOx emission increased from 8.4 to $11.3 \mathrm{Tg}$ year ${ }^{-1}$ and $\mathrm{NH}_{3}$ emission from 10.8 to $13.6 \mathrm{Tg}_{\text {year }}{ }^{-1}$ (Lu and Tian, 2007), and further increases are predicted (Chen and Mulder, 2007). The national average wet deposition of inorganic $\mathrm{N}$ was estimated to be $9.9 \mathrm{~kg} \mathrm{ha}^{-1}$ year ${ }^{-1}$ (Lu and Tian, 2007), which was higher than those in the United States $\left(3.0 \mathrm{~kg} \mathrm{ha}^{-1}\right.$ year $\left.^{-1}\right)$ and in Europe (6.8 $\mathrm{kg} \mathrm{ha}^{-1}$ year-1) (Holland et al., 2005). Increased $\mathrm{N}$ deposition can alter the $\mathrm{N}$ status of forest ecosystems through disturbances of the internal $\mathrm{N}$ cycle (Gundersen et al., 1998).

Evergreen broad-leaved forests, covering a large area in China, are the typical vegetation type in the subtropical area (Song and Chen, 2007). High atmospheric N deposition has already been observed in southern China, as in other parts of the world with rapid economic growth (Chen and Mulder, 2007; Jiang and Zhang, 2009; Fang et al., 2009). It has been hypothesized that moist tropical forest ecosystems are more sensitive to anthropogenic $\mathrm{N}$ load compared with temperate forest ecosystems (Matson et al., 1999). However, little is known about the $\mathrm{N}$ status, dynamics and leaching risk in these subtropical forests in China. Du et al. (2008) reported a high $\mathrm{N}$ deposition of $26.23 \mathrm{~kg} \mathrm{~N} \mathrm{ha}^{-1}$ year-1 $^{-1}$ in a subtropical forest over four years in the central China, in which no symptoms of $\mathrm{N}$ saturation were occurred and no indication of forest productivity declination was shown. The forest ecosystems of subtropical China may be different from those in temperate and boreal regions due to the different climate, species composition and soil properties. Relationships among soil $\mathrm{N}$ accumulation, soil $\mathrm{N}$ availability, and forest productivity are important for understanding long-term impacts of atmospheric
$\mathrm{N}$ deposition and fundamental for testing conceptual models of $\mathrm{N}$ limitation. Therefore, studies about the impacts of acid deposition on nitrogen status of forest ecosystems in subtropical China are of great importance. We determined the changes in $\mathrm{N}$ dynamics (including total $\mathrm{N}$, inorganic $\mathrm{N}\left(\mathrm{NH}_{4}^{+}-\mathrm{N}^{-}\right.$and $\mathrm{NO}_{3-}-\mathrm{N}$ ) concentrations, net ammonification and net nitrification potentials) and the potential for $\mathrm{N}$ leaching across a chronosequence of subtropical evergreen broad-leaved forest stands in order to assess the effects of increasing $\mathrm{N}$ deposition on $\mathrm{N}$ cycling in these subtropical forest ecosystems in eastern China.

\section{Materials and methods}

\subsection{Study site descriptions}

The study was conducted at the Laoshan Natural Reserve in Anhui, Eastern China $\left(30^{\circ} 20^{\prime} \mathrm{N}, 117^{\circ} 39^{\prime} \mathrm{E}\right.$, 110-900 $\mathrm{m}$ a.s.1.). The climate of this region is subtropical monsoon with a hot and humid summer and a dry and cold winter. The mean annual temperature is $16.4^{\circ} \mathrm{C}$, which ranges from a low of $3.6^{\circ} \mathrm{C}$ in January to a high of $28.2^{\circ} \mathrm{C}$ in July. The average annual precipitation is $1550 \mathrm{~mm}$ (range from $1220 \mathrm{~mm}$ to $1890 \mathrm{~mm}$ ) concentrated from May to August.

We employed the chronosequence approach in this study, selecting four upland evergreen broad-leaved forest stands that represented different stages of stand development. All stands are located within a $1 \mathrm{~km}$ radius of each other. Overstory tree species composition is dominated by evergreen broad-leaved trees such as Castanopsis sclerophlla Schott., C. eyrei Tutch., Cyclobalanopsis glauca Oerst., Lithocarpus glaber Makai., and deciduous broad-leaved species Liquidambar formosana Hance. The tree layer is $10-20 \mathrm{~m}$ high and the area covered by tree $80-90 \%$ of the total studied area. The coverages of shrub and herb layers are, respectively, $25-40 \%$ and $10-30 \%$. All stands were subjected to commercial harvesting followed by clear-cutting of remaining overstory trees. 
Table 1. Structural characteristics and site conditions along an age-sequence of the subtropical evergreen broadleaved forest on Laoshan Natural Reserve in Eastern China.

\begin{tabular}{|c|c|c|c|c|}
\hline Stand age (year after harvesting) & $18 \mathrm{yr}$ & $36 \mathrm{yr}$ & $48 \mathrm{yr}$ & $65 \mathrm{yr}$ \\
\hline Altitude (a.s.l., m) & 235 & 185 & 250 & 280 \\
\hline Slope $\left(^{\circ}\right)$ & 28 & 31 & 26 & 35 \\
\hline Aspect $\left({ }^{\circ}\right)$ & S11E & S8W & W17S & S13W \\
\hline Soil depth (cm) & 50 & 50 & 70 & 52 \\
\hline Soil texture & sandy loan & sandy loan & sandy loan & sandy loan \\
\hline Mean DBH $(\mathrm{cm})$ & 6.5 & 8.7 & 12.7 & 16.7 \\
\hline Mean tree height $(\mathrm{m})$ & 8 & 9 & 11 & 13 \\
\hline Tree density (Stems ha $\left.{ }^{-1}\right)$ & 4152 & 3465 & 3076 & 2492 \\
\hline Basal area of tree $\left(\mathrm{m}^{2} \mathrm{ha}^{-1}\right)$ & 25 & 29 & 54 & 65 \\
\hline $\begin{array}{l}\text { Coverage of underground } \\
\text { vegetation (\%) }\end{array}$ & 20 & 35 & 31 & 38 \\
\hline
\end{tabular}

$\mathrm{S}$ is south; $\mathrm{E}$ is east; $\mathrm{W}$ is west; $\mathrm{DBH}$ is diameter at the breast height.

Regeneration was allowed to proceed naturally. Vigorous regrowth of seed-dispersed pioneer trees, and tree stump and root sprouts is common in the studied sites. Permanent plots $(30 \mathrm{~m} \times 20 \mathrm{~m})$ were set up in each stands, which were located at the centre to eliminate edge effects. The chronosequence was based on tree-ring counts for at least 15 canopy trees per stand (Zhang et al., 2010a). The general characteristics of the sampling stands are given in Table 1.

The substrate parent materials are acidic intrusive rocks composing of sandstone and granite. The soil texture is mainly sandy loam with a granular structure on welldrained and steep slopes $\left(24-36^{\circ}\right)$, and soil $\mathrm{pH}$ ranges from 4.4 to 5.3. All stands are located on soil of shallow reddish yellow soils $(<1 \mathrm{~m}$ deep), classified as Haplic luvisols (Soil Survey Staff, 1999).

\subsection{Soil sampling}

Six $3 \mathrm{~m} \times 3 \mathrm{~m}$ subplots were randomly set up within each plot. In each subplot, we established a quadrat of $1.0 \mathrm{~m} \times 1.0 \mathrm{~m}$ in the centre for the forest floor sampling. After the collection of litter layer, the surface $(0-10 \mathrm{~cm})$ soil were collected at three points using an auger with an internal diameter of about $6.0 \mathrm{~cm}$. Soils collected within each subplot were combined to yield a single composite sample for the different layers and kept cool $\left(4-5^{\circ} \mathrm{C}\right)$ during transport to the laboratory. The composite soil samples were used for laboratory incubations and analysed for physicochemical soil properties. Additional $100-\mathrm{cm}^{3}$ soil cores were collected in each site to determine bulk densities for the soil layers of $0-10 \mathrm{~cm}$. Soil sampling was conducted in the middle of July (growing season) and December (dormant season) 2007. 


\subsection{Soil physicochemical properties}

The above-mentioned soil samples collected were air-dried, ground, passed through a $0.5-\mathrm{mm}$ sieve and analysed for some physiocchemical properties. The total $\mathrm{N}$ contents (TN) of both soil and forest floor materials were analyzed using an Auto-Kjeldahl Analyzer. The total contents of organic $\mathrm{C}$ (SOC) were determined using a $\mathrm{CN}$ analyzer (Multi N/C 3100, Jena Analytik). $\mathrm{C} / \mathrm{N}$ ratio was calculated as SOC divided by TN. Soil $\mathrm{pH}$ was determined by Horiba- $173 \mathrm{pH}$ meter in $1.0 \mathrm{~mol} \mathrm{l}^{-1} \mathrm{KCl}(1: 2.5)$ after end-over-end shaking for $1 \mathrm{~h}$ and a settling time of $15 \mathrm{~min}$.

Bulk density was determined only once in the growing season using 12 soil cores for each layer per stand. To measure the soil water condition, soil samples (15 g) were saturated with distilled water and then dried at $105^{\circ} \mathrm{C}$, after weighing at each step. Three indices of soil water were calculated: water content (WC), expressed as the weight of water in a sample divided by the weight of the dry soil sample ( $\mathrm{kg}$ water per $\mathrm{kg}$ dry soil); maximum water-holding capacity (MWHC), expressed as the weight of water in a water-saturated sample divided by the weight of the dry soil sample (kg water per $\mathrm{kg}$ dry soil), and water saturation ratio (WSR), defined as WC/MWHC.

\subsection{Nitrogen status}

We have also measured total $\mathrm{N}(\mathrm{TN}), \mathrm{NH}_{4}^{+}-\mathrm{N}\left(\mathrm{N}_{\mathrm{A}}\right)$; and $\mathrm{NO}_{3}{ }^{-}-\mathrm{N}(\mathrm{NN})$ concentrations, net ammonification $\left(\mathrm{N}_{\mathrm{AP}}\right)$; and net nitrification $\left(\mathrm{N}_{\mathrm{NP}}\right)$; potentials. Then we calculated: inorganic $\mathrm{N}$ concentration $\left(\mathrm{N}_{\mathrm{IN}}\right)$, the sum of $\mathrm{NH}_{4}^{+}-\mathrm{N}$ and $\mathrm{NO}_{3}^{-}-\mathrm{N}$ concentrations; and the net $\mathrm{N}$ mineralization potential $\left(\mathrm{N}_{\mathrm{MP}}\right)$; as the sum of net ammonification and nitrification potentials. Potential $\mathrm{N}$ transformation was determined by aerobic laboratory incubations. Each sample was separately sieved through a 5-mm mesh to separate roots and the gross fraction of soil. About $30 \mathrm{~g}$ of each fresh soil sample was incubated in a glass beaker at $30^{\circ} \mathrm{C}$ for 4 weeks (Zhang et al., 2010b). The water content of the incubated soil was kept at about $60 \%$ of the maximum water-holding capacity. The concentrations of inorganic $\mathrm{N}\left(\mathrm{NH}_{4}^{+}-\mathrm{N}\right.$ and $\left.\mathrm{NO}_{3}{ }^{-}-\mathrm{N}\right)$ in the soil were determined before and after the incubation.

The inorganic $\mathrm{N}$ concentrations were expressed on a dryweight basis. Soil samples were extracted with $60 \mathrm{~mL}$ of $2 \mathrm{M} \mathrm{KCl}$ for $1 \mathrm{~h}$ and filtered through Whatman GF/F glass microfiber filters. Ammonium- $\mathrm{N}$ and $\mathrm{NO}_{3}{ }^{-}-\mathrm{N}$ were then analyzed with a flow-injection autoanalyser (FOSS FIA Star 5000) using alkaline phenol and cadmium reduction techniques, respectively. Net $\mathrm{N}$ mineralization potential was calculated as the difference in inorganic $\mathrm{N}$ content before and after incubation. Net ammonification potential and net nitrification potential were calculated as the difference in $\mathrm{NH}_{4}^{+}-\mathrm{N}$ and $\mathrm{NO}_{3}^{-}{ }^{-} \mathrm{N}$ content before and after incubation, respectively. The extracts were also used for determining the dissolved organic $\mathrm{C}$ (DOC) and N (DON) by TOC autoanalyser (Multi N/C 3100, Jena Analytik).

\subsection{Throughfall and soil solution collection and analysis}

Incident rainfall was collected with a trough-type collector installed on support $1.0 \mathrm{~m}$ above ground outside the forests. And throughfall was collected with five collectors in each stands. The collector was made of $300 \mathrm{~mm}$ diameter plastic funnel, connected via flexible tube to 201 polyethylene container. The funnel was covered with a thin-mesh nylon net to prevent coarse material from entering the container. Soil solution was sampled using five zero-tension lysimeters installed in the wall of excavated soil pits at $30 \mathrm{~cm}$ depth $\left(\mathrm{S}_{30} \mathrm{~cm}\right)$ and under the forest floor $\left(\mathrm{S}_{0} \mathrm{~cm}\right)$, respectively. The sample collections were conducted twice monthly over the 2-yr period during 2006-2007. After each collection of solution samples, the containers were thoroughly washed. The water samples were collected in the polyethylene bottles that were pre-washed with dilute $(5 \%) \mathrm{HCl}$ then thoroughly rinsed with deionized water.All samples were returned to the laboratory and stored in a cooler at $4{ }^{\circ} \mathrm{C}$ immediately after collection. 
Table 2. Soil physicochemical properties along an age-sequence of the subtropical evergreen broad-leaved forest on Laoshan Natural Reserve in Eastern China. Values are means with S.E. in the parenthesis. Means with different letters within rows are statistically different at $p<0.05$.

\begin{tabular}{|c|c|c|c|c|}
\hline Forest floor $\mathrm{C}: \mathrm{N}$ ratio & $44(1.4) \mathrm{a}$ & $41(1.5) \mathrm{b}$ & $41(1.5) \mathrm{b}$ & $40(1.3) \mathrm{b}$ \\
\hline $\mathrm{pH}(\mathrm{KCl})$ & $4.0(0.12) a b$ & $4.1(0.13) \mathrm{a}$ & $3.8(0.13) \mathrm{b}$ & $3.6(0.12) \mathrm{c}$ \\
\hline Total org-C $\left(\mathrm{g} \mathrm{kg}^{-1}\right)$ & $40(2.5) \mathrm{a}$ & $41(2.9) \mathrm{a}$ & $53(2.4) \mathrm{b}$ & $60(2.5) \mathrm{c}$ \\
\hline Total N $\left(\mathrm{g} \mathrm{kg}^{-1}\right)$ & $2.8(0.13) \mathrm{a}$ & $2.7(0.11) a$ & $3.9(0.15) \mathrm{b}$ & $4.7(0.16) \mathrm{c}$ \\
\hline $\mathrm{C}: \mathrm{N}$ ratio & $14(0.26) \mathrm{a}$ & $15(0.27) \mathrm{b}$ & $13(0.21) \mathrm{c}$ & $13(0.30) \mathrm{c}$ \\
\hline Bulk density $\left(\mathrm{g} \mathrm{cm}^{-3}\right)$ & $1.2(0.03) \mathrm{a}$ & $1.2(0.03) \mathrm{a}$ & $1.1(0.03) \mathrm{b}$ & $1.0(0.03) \mathrm{c}$ \\
\hline Clay content (\%) & $18(1.9) \mathrm{a}$ & $12(1.4) \mathrm{b}$ & $23(2.1) \mathrm{c}$ & $27(2.2) \mathrm{d}$ \\
\hline WC $\left(\mathrm{kg} \mathrm{kg}^{-1}\right)$ & $0.23(0.04) \mathrm{a}$ & $0.21(0.04) \mathrm{a}$ & $0.28(0.04) b$ & $0.29(0.03) \mathrm{b}$ \\
\hline MWHC $\left(\mathrm{kg} \mathrm{kg}^{-1}\right)$ & $0.33(0.08) \mathrm{a}$ & $0.32(0.06) \mathrm{a}$ & $0.38(0.07) \mathrm{b}$ & $0.40(0.08) \mathrm{b}$ \\
\hline WSR & $0.68(0.04) \mathrm{a}$ & $0.65(0.05) \mathrm{a}$ & $0.74(0.05) \mathrm{b}$ & $0.75(0.03) \mathrm{b}$ \\
\hline
\end{tabular}

The solution samples were filtered through Whatman GF/F glass microfiber filters and then stored at $4{ }^{\circ} \mathrm{C}$ prior to analysis. The concentrations of $\mathrm{NH}_{4}^{+}-\mathrm{N}$ and $\mathrm{NO}_{3}^{-}-\mathrm{N}$ were analyzed with a flowinjection autoanalyser (FOSS FIA Star 5000). The concentrations of DOC and DON were determined by TOC autoanalyser (Multi N/C 3100, Jena Analytik). The fluxes were calculated as monthly mean concentration timing the related volume in the month. The annual flux is the sum of the flux each month within a year.

\subsection{Statistical analyses}

Because of the unique nature of the chronosequence, there is no true replication of stand age. The soil $\mathrm{N}$ parameters and physicochemical properties were used to evaluate differences by one-way analysis of variance (ANOVA). Tukey HSD tests were used to distinguish differences among forest stands at $p<$ 0.05 . All statistical analyses were performed using SPSS 11.1 for Windows (Stat Soft Inc., 2004). 


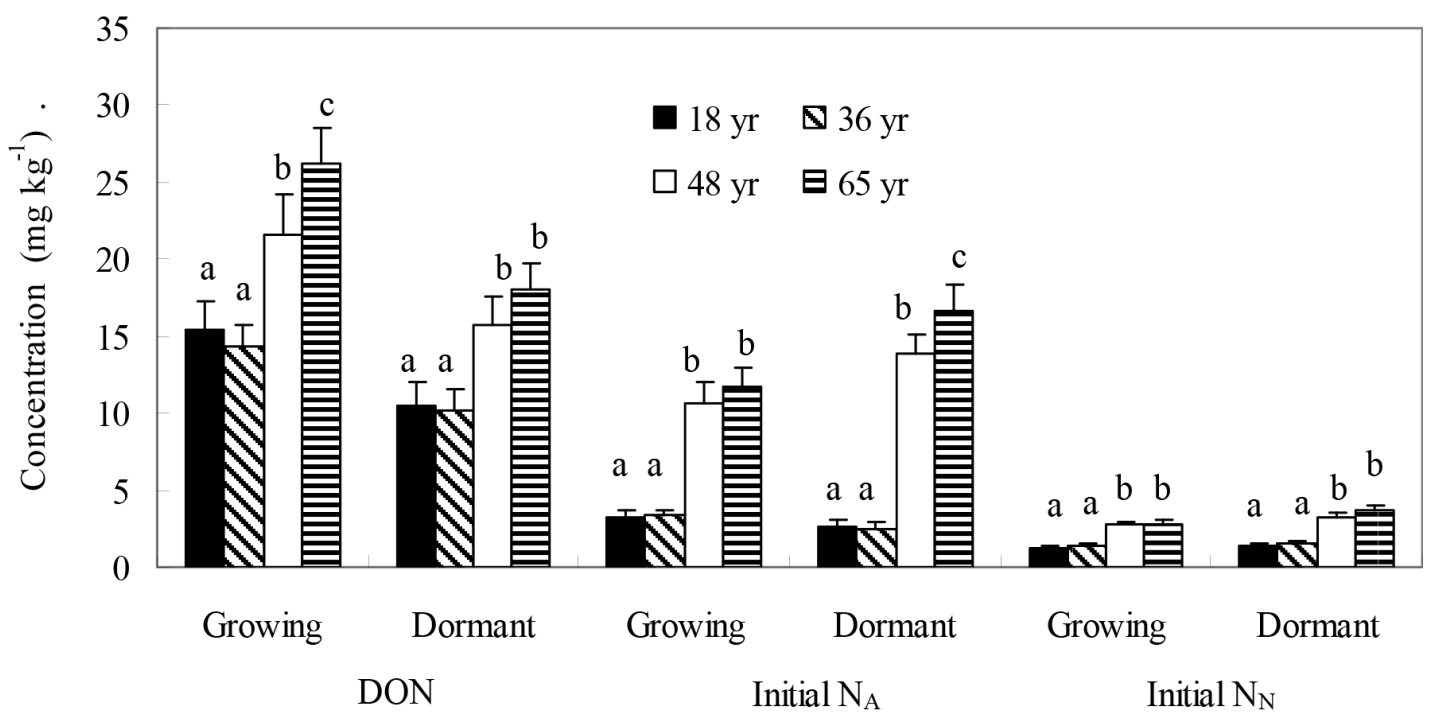

Figure 1. Comparison in concentrations of inorganic $\mathrm{N}$ and dissolved organic $\mathrm{N}(\mathrm{DON})$ in surface mineral soil along an age-sequence of subtropical evergreen broad-leaved forest on Laoshan Natural Reserve in Eastern China. Letters above the bars indicate significant differences at $p<0.05$.

Pearson correlation analysis was used to examine relationships among soil properties as necessary. All statistical were considered significant at the $p<0.05$.

\section{Results}

\subsection{Soil physicochemical properties}

There were significant differences in soil physicochemical properties among forest stands along the age sequence (Table 2). The $\mathrm{C} / \mathrm{N}$ ratio of the forest floor organic matter was significantly higher in the 18year stand than in the other stands. Soil bulk density and $\mathrm{pH}$ were significantly lower in the old stands (48and 65-year) than in the young stands (18- and 36year). However, the concentrations of SOC and total N were higher in the old stands than in the young stands.
Soil $\mathrm{C} / \mathrm{N}$ ratio was highest in 36-year stand and lowest in $65^{-\mathrm{yr}}$ stand for the $0-10 \mathrm{~cm}$ soil layer (Table 2).

Significant differences among forest stands were found in both WC and MWHC (Table 2). Soil moisture conditions were higher in the old stands than in the young stands. The result indicates that there are distinct differences in soil moisture conditions among forest stands along the age sequence.

\subsection{Soil $N$ forms, net $N$ transformation rates}

Significant differences were in soil $\mathrm{N}$ availability between the chronosequent stands (Figure 1). The initial concentrations of inorganic $\mathrm{N}$ were low in the young stands (4.0-4.8 $\mathrm{mg} \mathrm{kg}^{-1}$ ) and high in the older stands (13-20 mg kg-1). The initial concentration of $\mathrm{NO}_{3}^{-}-\mathrm{N}$ was relatively low in all stands in both growing (1.3$2.8 \mathrm{mg} \mathrm{kg}^{-1}$ ) and dormant seasons (1.4-3.8 $\mathrm{mg} \mathrm{kg}^{-1}$ ). 


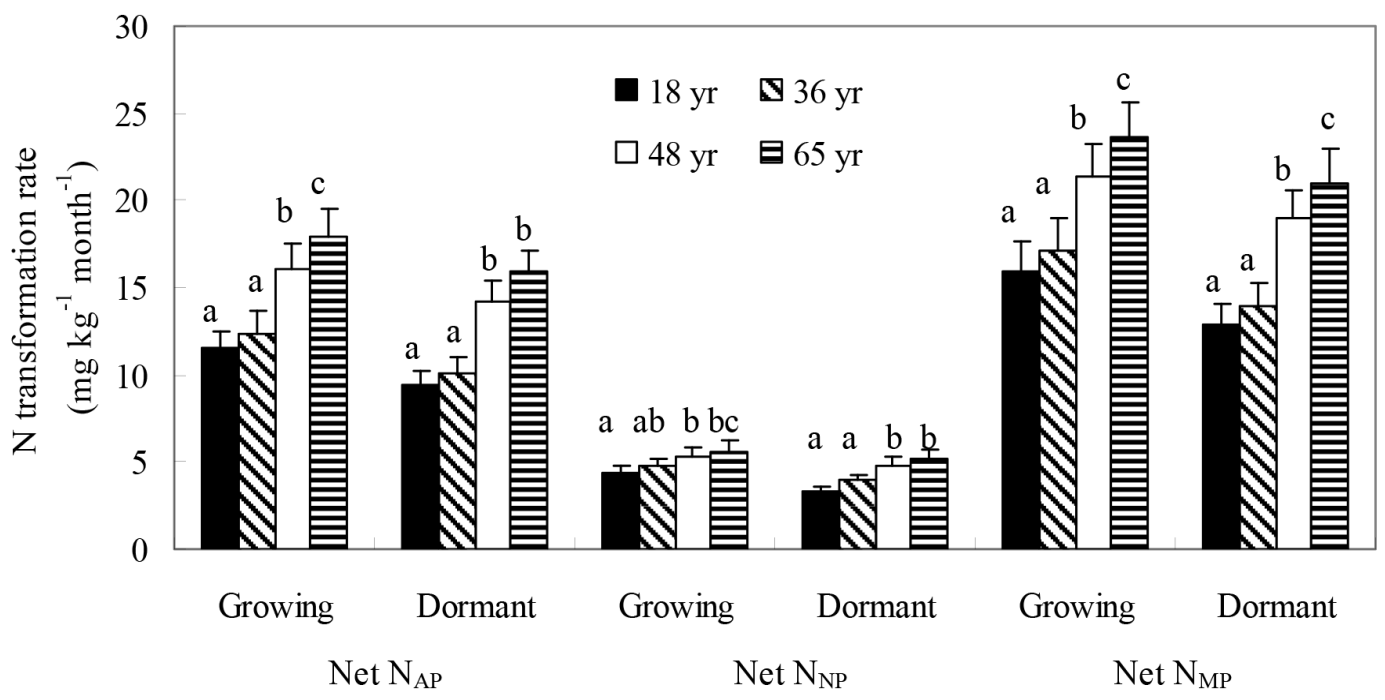

Figure 2. The rate of potential net $\mathrm{N}$ transformation in the surface $10 \mathrm{~cm}$ of mineral soil along an age-sequence of subtropical evergreen broad-leaved forest on Laoshan Natural Reserve in Eastern China. Letters above the bars indicate significant differences at $p<0.05$.

In the old stands (48- and 65-year), no significant difference was observed in the percentage of total inorganic $\mathrm{N}$ present as $\mathrm{NO}_{3}{ }^{-} \mathrm{N}$ between the growing and dormant seasons $(p>0.05)$. However, the percentage of $\mathrm{NO}_{3}{ }^{-}-\mathrm{N}$ was significantly greater in the dormant season than in the growing season $(p<0.01)$ in the 18- and 36-year stands (Figure 1).

Significant differences were observed in net mineralization potential, and net ammonification potential among forest stands (Figure 2). The net ammonification potentials were greater in the growing season than in the dormant season for all stands. Furthermore, the rates of net ammonification potential were significantly higher than that of net nitrification potential in all stands studied $(p<0.01)$. Owing to this clear difference in net ammonification potential among forest stands, there were significant differences in net mineralization potential between the growing and dormant seasons for all the stands $(p<0.05)$.
The net mineralization potentials in the old stands (48- and 65-year) were $30-55 \%$ higher than those in the young stands (18- and 36-year).

Results of linear regression analysis showed that the net $\mathrm{N}$ transformation potentials were significantly and positively correlated with SOC, TN, DOC, WC and $\mathrm{MWHC}$, and negatively correlated with soil $\mathrm{pH}, \mathrm{C} / \mathrm{N}$ ratio and bulk density (Table 3 ). However, no significant correlation between forest floor $\mathrm{C} / \mathrm{N}$ ratio and net $\mathrm{N}$ transformation potential $(p>0.33)$ were detected (Table 3).

\subsection{Atmospheric input and potential leaching of $N$}

In the two years period the total atmospheric $\mathrm{N}$ deposition input was $18 \mathrm{~kg} \mathrm{ha}^{-1}$ year $^{-1}$, of which $60 \%$ due to inorganic $\mathrm{N}$ and $40 \%$ due to DON. 
Table 3. Pearson correlation coefficients and $p$ values (italic) for the potential $\mathrm{N}$ transformation indices and soil physicochemical properties of the subtropical evergreen broad-leaved forest on Laoshan Natural Reserve in Eastern China

\begin{tabular}{|c|c|c|c|c|c|c|c|c|c|c|c|c|}
\hline $\begin{array}{c}\text { Soil } \\
\text { indices }\end{array}$ & $\begin{array}{c}\text { FF C:N } \\
\text { ratio }\end{array}$ & $\begin{array}{c}\mathrm{pH} \\
(\mathrm{KCl})\end{array}$ & SOC & TN & $\begin{array}{c}\text { Soil C:N } \\
\text { ratio }\end{array}$ & DON & $\mathrm{N}_{\mathrm{IN}}$ & $\begin{array}{c}\text { Clay } \\
\text { content }\end{array}$ & $\mathrm{BD}$ & WC & MWHC & WSR \\
\hline \multirow[t]{2}{*}{$\mathrm{N}_{\mathrm{AP}}$} & -0.395 & -0.833 & 0.896 & 0.929 & -0.913 & 0.838 & 0.788 & 0.832 & -0.901 & 0.956 & 0.910 & 0.858 \\
\hline & 0.333 & 0.011 & 0.003 & 0.001 & 0.002 & 0.009 & 0.063 & 0.010 & 0.002 & 0.000 & 0.002 & 0.006 \\
\hline \multirow[t]{2}{*}{$\mathrm{N}_{\mathrm{NP}}$} & -0.278 & -0.667 & 0.771 & 0.811 & -0.819 & 0.725 & 0.661 & 0.669 & -0.797 & 0.899 & 0.796 & 0.885 \\
\hline & 0.504 & 0.071 & 0.025 & 0.015 & 0.013 & 0.042 & 0.193 & 0.070 & 0.018 & 0.002 & 0.018 & 0.003 \\
\hline \multirow[t]{2}{*}{$\mathrm{N}_{\mathrm{MP}}$} & -0.381 & -0.809 & 0.879 & 0.914 & -0.902 & 0.820 & 0.772 & 0.808 & -0.890 & 0.951 & 0.895 & 0.868 \\
\hline & 0.353 & 0.015 & 0.004 & 0.001 & 0.002 & 0.013 & 0.077 & 0.015 & 0.003 & 0.000 & 0.003 & 0.005 \\
\hline
\end{tabular}

Throughfall $\mathrm{N}$ fluxes varied greatly between stands, ranging from 17 to $23 \mathrm{~kg} \mathrm{ha}^{-1}$ year $^{-1}$ with a trend that increased with stand age (Table 4). Inorganic $\mathrm{N}$ fluxes due to throughfall were lower in the two young stands (18- and 36-year) while higher in the old stands (48- and 65-year) than those of the atmospheric deposition.

Total inorganic $\mathrm{N}$ concentration in soil water under the forest floor (S0) and at $30 \mathrm{~cm}$ depth (S30) ranged from 0.82 to $1.1 \mathrm{mg} \mathrm{l}^{-1}$ and from 0.47 to $0.65 \mathrm{mg} \mathrm{l}^{-1}$, respectively. The ratios of $\mathrm{NO}_{3}^{-}-\mathrm{N}$ concentration to total inorganic $\mathrm{N}$ concentration were significantly greater in the young stands $(0.75-0.77)$ than in the old stands $(0.63-0.64 ; p<0.05)$. The total $\mathrm{N}$ fluxes were from 7.3 to $9.3 \mathrm{~kg} \mathrm{ha}^{-1}$ year $^{-1}$ at $\mathrm{S}_{0} \mathrm{~cm}$ and from 1.2 to $2.5 \mathrm{~kg} \mathrm{ha}^{-1}$ year $^{-1}$ at $\mathrm{S}_{30} \mathrm{~cm}$ along the age sequence, with the high values in the old stand (Table 4).

\section{Discussion}

\subsection{Controls for $N$ dynamics}

worldwide. Studies conducted in Europe and Northeast America made clear that the soil $\mathrm{N}$ status is the key to analyze effects of increasing anthropogenic $\mathrm{N}$ deposition on forest ecosystem processes (Brumme and Khanna, 2008). Several indicators for $\mathrm{N}$ status have been identified for temperate and boreal forest ecosystems. Most commonly used are N concentration and $\mathrm{C} / \mathrm{N}$ ratio of the forest floor (e.g., Dise et al., 1998; Gundersen et al., 1998; Bengtsson et al., 2003). As the soils under evergreen broad-leaved forests lack a welldeveloped forest floor in subtropical China, indicators for $\mathrm{N}$ status should be evaluated.

The determined $\mathrm{N}$ transformation rates were significantly and positively correlated with soil total organic $\mathrm{C}$, total N, DON concentrations; and negatively correlated with soil $\mathrm{C} / \mathrm{N}$ ratio but not with forest floor $\mathrm{C} / \mathrm{N}$ ratio and inorganic $\mathrm{N}$ concentration (Table 3 ). The correlation for mineral soil horizon do not agree with results of temperate and boreal forest soils (Dise et al., 1998; Bengtsson et al., 2003), which can be attributed to the difference in the distribution pattern of $\mathrm{C}$ and $\mathrm{N}$ 
Table 4. Concentrations and fluxes of dissolved organic $\mathrm{C}$ (DOC), dissolved organic $\mathrm{N}$ (DON), $\mathrm{NH}_{4}^{+}-\mathrm{N}$ and $\mathrm{NO}_{3}{ }^{-}$ -N of soil solutions along an age-sequence of the subtropical evergreen broad-leaved forest on Laoshan Natural Reserve in Eastern China

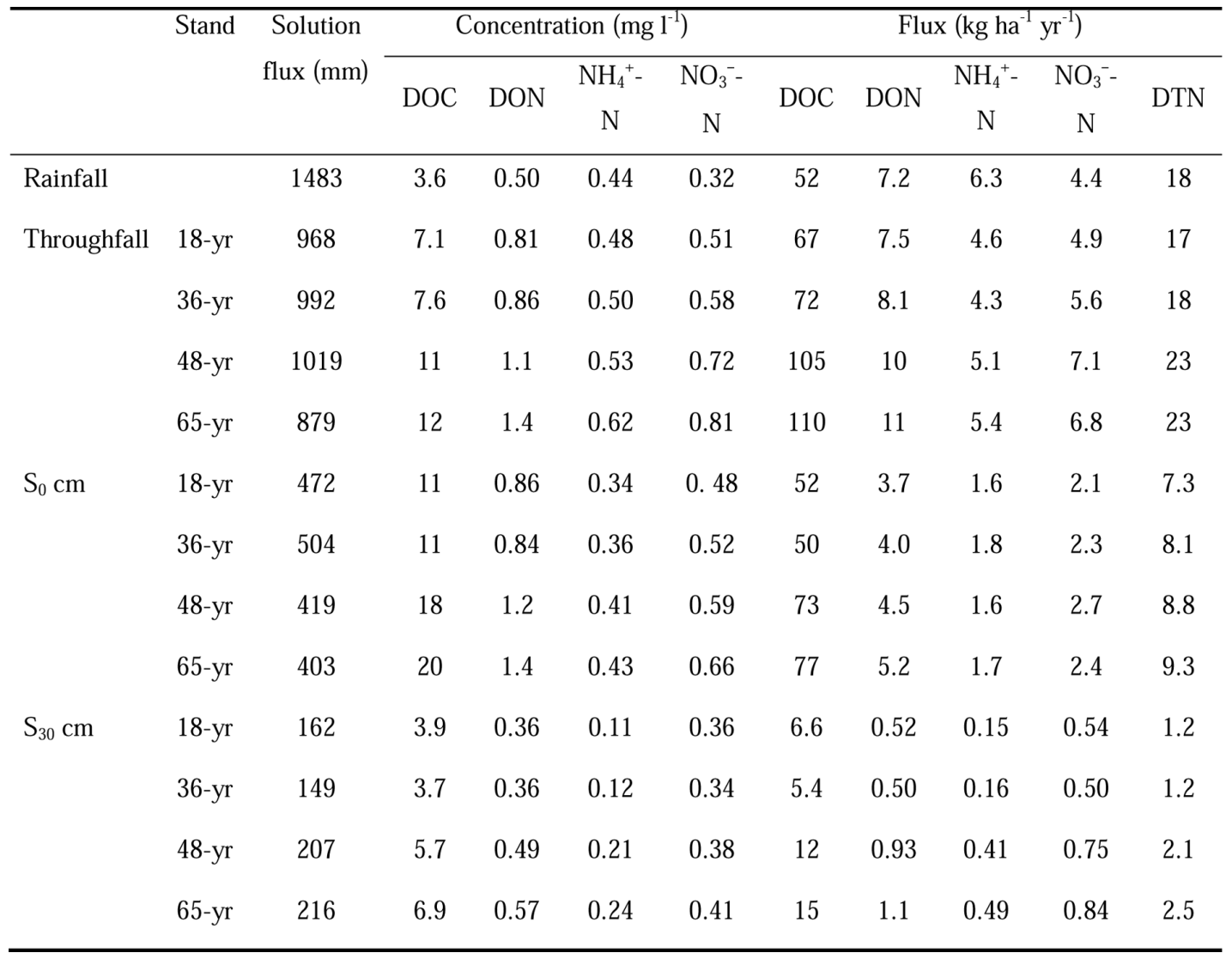

DTN is the total dissolved nitrogen.

in soils. Compared with subtropical and tropical forests, the forest floor made a high contribution to the total organic $\mathrm{C}$ and $\mathrm{N}$ pools of soil in temperate and boreal forests (Vogt et al., 1986). In subtropical and tropical area, the forests usually have a great turnover rate of forest floor organic matter due to the warm and wet climate, which made the forests lack a well-developed forest floor. Consequently the forest floor $\mathrm{C} / \mathrm{N}$ the ratio cannot be used as an indicator for the $\mathrm{N}$ status in this subtropical forest ecosystem. The quality or degradability of soil organic matter may be the major controlling factors for the net $\mathrm{N}$ transformation rates (Bengtsson et al., 2003). Therefore, the $\mathrm{C} / \mathrm{N}$ ratio and $\mathrm{DON}$ concentration in the surface mineral soil could be used as a predictor of net $\mathrm{N}$ mineralization rate in this subtropical forest. Our finding was in agreement with the result reported by Chen and Mulder (2007) and Perakis and Sinkhorn (2011). 
This study demonstrates that the concentrations of $\mathrm{N}$ forms and the net $\mathrm{N}$ transformation rates varied during the forest development with higher $\mathrm{N}$ availability in the older stands than in the young stands. The previous study showed that the litterfall produced by the young stands had relatively low concentrations of $\mathrm{N}$ and $\mathrm{P}$, which resulted in a high $\mathrm{C} / \mathrm{N}$ and $\mathrm{C} / \mathrm{P}$ ratios for the forest floor (Wang et al., 2010). Consequently, these changes could affect the $\mathrm{N}$ mineralization in litter decomposition and finally result in the decreasing of soil $\mathrm{N}$ availability. It is in agreement to the result from a study conducted in subtropical broad-leaved forests in Puerto Rico that suggested litterfall $\mathrm{C} / \mathrm{N}$ ratio directly controlled soil $\mathrm{N}$ processes and was an indicator of $\mathrm{N}$ status (Erickson et al., 2002). In addition, soil physical properties also correlated with the net rates of $\mathrm{N}$ mineralization. Our results showed that the potential $\mathrm{N}$ transformation rates were significantly and positively correlated with clay content and moisture conditions and negatively correlated with bulk density (Table 4). In the tropical lowland forests, there is substantial evidence that soil texture influences soil $\mathrm{N}$ status (Luizão et al., 2004; Silver et al., 2005). Those results suggest that the substrate quality is a major control of soil $\mathrm{N}$ availability and $\mathrm{N}$ losses.

The rates of net ammonification potential were significantly higher than that of net nitrification potential in all forest stands at our site. The $\mathrm{NO}_{3}{ }^{-} \mathrm{N}$ pool contributed only $19-33 \%$ of the soil inorganic $\mathrm{N}$ pools. However, the fluxes of $\mathrm{NO}_{3}{ }^{-}-\mathrm{N}$ under the forest floor and at 30-cm soil depth contributed $56-62 \%$ and $63-78 \%$ of the total inorganic $\mathrm{N}$ fluxes, respectively. This suggests that $\mathrm{NH}_{4}^{+}$cycles faster than $\mathrm{NO}_{3}^{-}$in our forest site. The mechanism for the higher conversion of $\mathrm{NH}_{4}^{+}$than $\mathrm{NO}_{3}^{-}$is presently unknown and cannot be deduced from the present study, which needs further study in this subtropical forest.

\subsection{Critical loads of $N$ deposition and potential $N$ leaching}

Elevated $\mathrm{NO}_{3}{ }^{-}-\mathrm{N}$ loss to surface waters was defined as the primary symptom of $\mathrm{N}$ excess in forest ecosystem and a critical signal of $\mathrm{N}$ saturation (Aber et al., 1989). Nitrogen losses from forests has become an important research area and public policy issue in recent years because $\mathrm{N}$ leaching can strip nutrients from forest soils, acidify streams, and cause eutrophication (Fenn et al., 1998; Lovett et al., 2002). Nitrogen deposition and $\mathrm{N}$ leaching loss from the forest ecosystems in southern China were given in Table 5, which were greater than 3.5-11 kg ha ${ }^{-1}$ year $^{-1}$ in Japanese forests (Mitchell et al., 1997), just similar to $9.0-33 \mathrm{~kg} \mathrm{ha}^{-1}$ year $^{-1}$ at NITREX sites in Europe (Gundersen et al., 1998) and in California, USA (Fenn et al., 1998). The average annual total inorganic $\mathrm{N}$ deposition in bulk precipitation at our site $\left(11 \mathrm{~kg} \mathrm{ha}^{-1}\right.$ year $\left.^{-1}\right)$ is intermediate between the low level $\left(3.3 \mathrm{~kg} \mathrm{ha}^{-1}\right.$ year $^{-1}$ ) in Ailao Mountain of Yunnan (Liu et al., 2003) and the very high level $\left(34 \mathrm{~kg} \mathrm{ha}^{-1}\right.$ year $\left.^{-1}\right)$ recorded in Dinghushan close to Guangzhou (Fang et al., 2009). The $\mathrm{N}$ deposition rate at our site was similar to the high level in Japanese forest with $\mathrm{N}$ saturation (Mitchell et al., 1997).

The inorganic $\mathrm{N}$ leaching loss from forests in subtropical China was averaged from 0.57 to $6.2 \mathrm{~kg}$ ha $^{-1}$ year $^{-1}$ (Table 5) except for a site at Dinghushan, Guangzhou shown the status of N saturation with a leaching loss from the active rooting zone of 29 $\mathrm{kg} \mathrm{ha}^{-1}$ year $^{-1}$. The annual input-output budget of inorganic $\mathrm{N}$ for subtropical Chinese forest reaches from $2.7 \mathrm{~kg} \mathrm{ha}^{-1}$ year $^{-1}$ in Ailao Mountain of unpolluted region with a very low deposition (3.3 $\mathrm{kg} \mathrm{ha}^{-1}$ year ${ }^{-1}$ ) to $24 \mathrm{~kg} \mathrm{ha}^{-1}$ year $^{-1}$ in Shaoshan, Changsha with a very high deposition of $26 \mathrm{~kg} \mathrm{ha}^{-1}$ year ${ }^{-1}$.

Values for annual budget of inorganic $\mathrm{N}$ were much higher than other studied sites in Europe and Japan, indicating that $\mathrm{N}$ is still a limiting factor to forest growth in subtropical China. 
Table 5. Comparison of inorganic $\mathrm{N}$ inputs by precipitation and output by stream-water in some forest ecosystems in subtropical China.

\begin{tabular}{|c|c|c|c|c|c|c|c|c|}
\hline \multirow[t]{2}{*}{ Site } & \multirow[t]{2}{*}{$\begin{array}{l}\text { Precipitation } \\
\qquad(\mathrm{mm})\end{array}$} & \multicolumn{3}{|c|}{$\begin{array}{c}\text { Inputs by } \\
\text { precipitation }\left(\mathrm{kg} \mathrm{ha}^{-1}\right. \\
\left.\mathrm{yr}^{-1}\right)\end{array}$} & \multicolumn{3}{|c|}{$\begin{array}{l}\text { Output by stream } \\
\left.\qquad \mathrm{kg} \mathrm{ha}^{-1} \mathrm{yr}^{-1}\right)\end{array}$} & \multirow[t]{2}{*}{ Reference } \\
\hline & & $\mathrm{N}_{\mathrm{A}}$ & $\mathrm{N}_{\mathrm{N}}$ & $\mathrm{N}_{\text {IN }}$ & $\mathrm{N}_{\mathrm{A}}$ & $\mathrm{N}_{\mathrm{N}}$ & $\mathrm{N}_{\text {IN }}$ & \\
\hline Tieshanping, Chongqing & 1229 & 18 & 8.7 & 27 & 0.05 & 6.1 & 6.2 & Jiang et al. (2009) \\
\hline Shaoshan, Hunan & 1251 & 17 & 9.3 & 26 & 0.09 & 2.1 & 2.2 & Du et al. (2008) \\
\hline Dinghushan,Guangzhou* & 1927 & 23 & 11 & 34 & 3.8 & 25 & 29 & Fang et al. (2009) \\
\hline Ailaoshan, Yunnan & 1931 & 2.7 & 0.61 & 3.3 & 0.34 & 0.23 & 0.57 & Liu et al. (2003) \\
\hline Xiaokeng, Anhui* & 1483 & 6.3 & 4.4 & 11 & 0.31 & 0.66 & 0.97 & This study \\
\hline
\end{tabular}

* Nitrogen leaching loss under the active rooting zone.

Input-output budgets from forests in Europe and North America have shown that the $\mathrm{N}$ input (inorganic $\mathrm{N}$ in throughfall) threshold for elevated $\mathrm{NO}_{3}^{-}$leaching was at approximately $10 \mathrm{~kg} \mathrm{ha}^{-1}$ year $^{-1}$ (Dise et al., 2009). Studies in the Japanese forests have confirmed this critical load of $\mathrm{N}$ deposition (Mitchell et al., 1997). Whereas studies in California provided evidence for $\mathrm{N}$ saturation with $\mathrm{N}$ deposition rates around $25 \mathrm{~kg} \mathrm{ha}^{-1}$ year $^{-1}$ (Fenn et al., 1998). Although high inorganic $\mathrm{N}$ deposition has been found in subtropical Chinese forest ecosystems, and the total input fluxes of inorganic $\mathrm{N}$ has even exceeded the abovementioned threshold $25 \mathrm{~kg} \mathrm{ha}^{-1}$ year $^{-1}$, surprisingly $\mathrm{N}$ saturation did not appear, and no indication of decline in forest productivity has been shown. The results indicate that the subtropical Chinese forest is still a finer buffering system to $\mathrm{N}$ deposition, and proper $\mathrm{N}$ deposition will not lead to acidification of surface and stream water. The $\mathrm{N}$ flux in surface 30 - $\mathrm{cm}$ soil depth was $6.2 \%-13 \%$ of annual inorganic $\mathrm{N}$ deposition at our site. This suggests that the root - microbial system in the upper soil horizon in retaining over $88 \%$ of $\mathrm{N}$ deposited. Given the high $\mathrm{N}$ retention and very low leaching loss inorganic $\mathrm{N}$ below the active rooting zone, these subtropical forests may be providing a great service in retention of exogenous $\mathrm{N}$ and buffering downstream ecosystems of $\mathrm{N}$ pollution.

In addition, the $\mathrm{N}$ mineralization rate, an important process regulating $\mathrm{N}$ dynamics, has been suggested as an index for potential risk of $\mathrm{N}$ leaching in forest ecosystems (Perakis and Sinkhorn, 2011). At our site, the annual $\mathrm{N}$ mineralization potential in the surface $10 \mathrm{~cm}$ of the mineral soil was significant correlation with the total inorganic $\mathrm{N}$ concentration of soil solution at the $30 \mathrm{~cm}$ depth (Figure 3). This suggests that $\mathrm{N}$ mineralization is an important contributing factor to $\mathrm{N}$ leaching in this subtropical forest. 


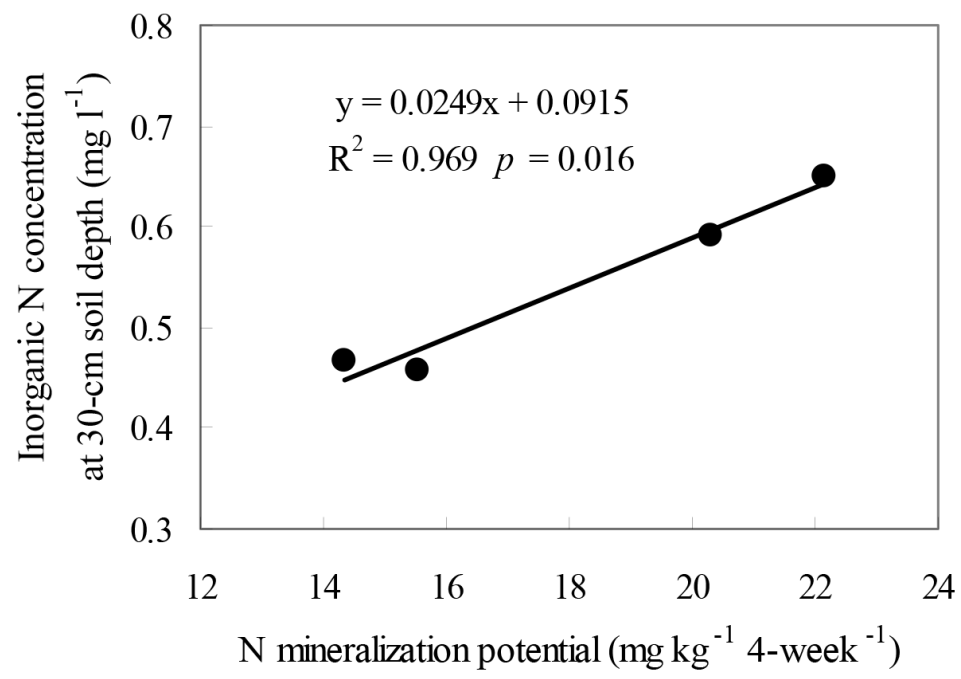

Figure 3. Relationship between inorganic $\mathrm{N}$ concentration in soil solution at $30-\mathrm{cm}$ depth and soil $\mathrm{N}$ mineralization potential along an age-sequence of subtropical evergreen broad-leaved forest on Laoshan Natural Reserve in Eastern China.

Some studies reveal that without disturbance, young forests are expected to actively accumulate and store $\mathrm{N}$ as forest biomass increases with relatively low $\mathrm{N}$ loss while older forests are more likely to export $\mathrm{NO}_{3}^{-}$to stream and ground waters (Aber et al., 1989). Our data support this finding. The mean net $\mathrm{N}$ mineralization rates for the surface $10-\mathrm{cm}$ soil by laboratory incubation ranged from 13 to 22 $\mathrm{mg} \mathrm{kg}^{-1} \mathrm{month}^{-1}$, which were significantly higher in the old stands than in the younger stands (Figure 2). Due to a significant correlation between the net $\mathrm{N}$ mineralization rate and inorganic $\mathrm{N}$ leaching below the rooting zone, it raises the possibility that $\mathrm{NO}_{3}^{-}$ leaching is just a function of successional controls over soil $\mathrm{N}$ stocks. That is, $\mathrm{N}$ status varies as a function of forest age and not $\mathrm{N}$ deposition in this subtropical secondary forest.

\section{Conclusions}

The results from the present study showed that the soil $\mathrm{N}$ status varied during the forest development with higher $\mathrm{N}$ availability in the older stands than in the young stands. The potential $\mathrm{N}$ transformation rates were significantly higher in the older stands than in the young stands, which were correlated with soil $\mathrm{C} / \mathrm{N}$ ratio and $\mathrm{DON}$ concentration, while not significantly correlated with forest floor $\mathrm{C} / \mathrm{N}$ ratio and inorganic $\mathrm{N}$ concentration. This indicates that both the $\mathrm{C} / \mathrm{N}$ ratio and $\mathrm{DON}$ concentration of mineral soil, rather than forest floor $\mathrm{C} / \mathrm{N}$ ratio, may be a promising indicator for $\mathrm{N}$ status of this subtropical forest. Our combined results showed that the $\mathrm{N}$ fluxes at $30-\mathrm{cm}$ soil depth had significant correlation with the potential $\mathrm{N}$ transformation rates. Thus the potential $\mathrm{N}$ transformation rate can be used as indicators for potential $\mathrm{N}$ leaching in our site. Furthermore, our findings of great net rates of ammonification potential with high $\mathrm{NH}_{4}^{+}$deposition 
signified that $\mathrm{NH}_{4}^{+}$cycles faster than $\mathrm{NO}_{3}^{-}$, possibly contributing to better retention of $\mathrm{NH}_{4}^{+}$than $\mathrm{NO}_{3}^{-}$, which the importance of biotic and abiotic $\mathrm{N}$ retention needs further attention.

\section{Acknowledgements}

The financial supports from National Natural Science Foundation of China (NSFC) through grant number 30771719 and 30471386 are gratefully acknowledged. The authors would like to thank Mr. Wang Shifeng for field support throughout the study period. Mrs. Lan Changchun, Liu Bo, Yu Yanfeng, Zhang Yunqi and Ding Zengfa helped for data collection from the field and laboratory analysis. Prof. Xu Xingkai reviewed the draft and gave valueable comments.

\section{References}

Aber, J.D. Nadelhoffer, K.J., Steudler, P., Melillo, J.M. 1989. Nitrogen saturation in northern forest ecosystems. BioScience. 39, 378-386.

Bengtsson, G., Bengtson, P., Månsson, K.F. 2003. Gross nitrogen mineralization, immobilization, and nitrification rates as a function of soil $\mathrm{C} / \mathrm{N}$ ratio and microbial activity. Soil Biol. Biochem. $35,143-154$.

Borken, W., Matzner, E. 2004. Nitrate leaching in forest soils: an analysis of long-term monitoring sites in Germany. J. Plant Nutrit. Soil Sci. 167, 277-283

Brumme, R., Khanna, P.K. 2008. Ecological and site historical aspects of $\mathrm{N}$ dynamics and current $\mathrm{N}$ status in temperate forests. Glob. Change Biol. $14,125-141$.

Chen, X.Y., Mulder, J. 2007. Indicators for nitrogen status and leaching in subtropical forest ecosystems, South China. Biogeochemistry. 82, 165-180.
Corre, M.D., Beese, F.O., Brumme, R. 2003. Soil nitrogen cycle in high nitrogen deposition forest: changes under nitrogen saturation and liming. Ecol. Appl. 13, 287-298.

Dise, N.B., Matzner, E., Forsius, M. 1998. Evaluation of organic horizon $\mathrm{C}: \mathrm{N}$ ratio as an indicator of nitrate leaching in conifer forests across Europe. Environmental Pollution. 102, 453-456.

Dise, N.B., Rothwell, J.J., Gauci, V., van der Salm, C., de Vries, W. 2009. Predicting dissolved inorganic nitrogen leaching in European forests using two independent databases. Sci. Total Environ. 407, 1798-1808.

Du, C.Y., Zeng, G.M., Zhang, G., Tang, L., Li, X.D., Huang, D.L., Huang, L., Jiang, Y.M. 2008. InputOutput Budgets for Inorganic Nitrogen Under Acid Rain in a Subtropical Evergreen Mixed Forest in Central-South China. Water Air Soil Pollut. 190, 171-181.

Erickson, H., Davidson, E.A., Keller, M. 2002. Former land-use and tree species affect nitrogen oxide emissions from a tropical dry forest. Oecologia. 130, 297-308.

Fang, Y.T., Yoh, M., Mo, J.M., Gundersen, P., Zhou, G.Y. 2009. Response of nitrogen leaching to nitrogen deposition in disturbed and mature forests of southern China. Pedosphere. 19, 111-120.

Fenn, M.E., Poth, M.A., Aber, J.D., Baron, J.S., Bormann, B.T., Johnson, D.W., Lemly, A.D., McNulty, S.G., Ryan, D.F., Stottlemeyer, R. 1998. Nitrogen excess in North American ecosystems: predisposing factors, ecosystem responses and management strategies. Ecol. Appl. 8, 706-733.

Gundersen, P., Emmett, B.A., Kjønaas, O.J., Koopmans, C.J., Tietema, A. 1998. Impact of nitrogen deposition on nitrogen cycling in forests: a synthesis of NITREX data. For. Ecol. Manage. 101, 37-55. 
Holland, E.A., Braswell, B.H., Sulzman, J., Lamarque, J.F. 2005. Nitrogen deposition onto the United States and Western Europe: synthesis of observation and models. Ecol. Appl. 15, 38-57.

Jiang, C.L., Zhang, X.S. 2009. N isotopes and N cycle in the Tieshanping subtropical forest ecosystem, Southwestern China. Environ. Monit. Assess. 154, 301-308.

Liu, W., Fox, J.E.D., Xu, Z. 2003. Nutrient budget of a montane evergreen broad-leaved forest at Ailao Mountain National Nature Reserve, Yunnan, southwest China. Hydrol. Process. 17, 1119-1134.

Lovett, G.M., Weathers, K.C., Arthur, M.A. 2002. Control of nitrogen loss from forested watersheds by soil carbon : nitrogen ratio and tree species composition. Ecosystems. 5, 712-718.

Lu, C., Tian, H. 2007. Spatial and temporal patterns of nitrogen deposition in China: Synthesis of observational data. J. Geophys. Res. 112, D22S05, doi 10.1029/2006JD007990.

Luizão, R.C.C., Luizão, F.J., Paiva, R.Q., Monteiro, T.F., Sousa, L.S., Kruijt, B. 2004. Variation of carbon and nitrogen cycling processes along a topographic gradient in a central Amazonian forest. Glob. Change Biol. 10, 592-600.

Matson, P.A., McDowell, W.H., Townsend, A.R. Vitousek, P.M. 1999. The globalization of $\mathrm{N}$ deposition: Ecosystem consequences in tropical environments. Biogeochemistry. 46, 67-83.

Mitchell, M.J., Iwatsubo, G., Ohrui, K., Nakagawa, Y. 1997. Nitrogen saturation in Japanese forests: An evaluation. For. Ecol. Manage. 97, 39-51.

Perakis, S.S., Sinkhorn, E.R. 2011. Biogeochemistry of a temperate forest nitrogen gradient. Ecology. 92, 14811491.

Silver, W.L., Thompson, A.W., Reich, A., Ewel, J.J., Firestone, M.K. 2005. Nitrogen cycling in tropical plantation forests: potential controls on nitrogen retention. Ecol. Appl. 15, 1604-1614.

Soil Survey Staff . 1999. Soil Taxonomy: A Basic System of Soil Classification for Making and Interpreting Soil Surveys. US Department of Agriculture Soil Conservation Service, Washington.

Song, Y.C., Chen, X.Y. 2007. Degradation Mechanism and Ecological Restoration of Evergreen Broadleaved Forest Ecosystem in East China, Science Press, Beijing, China, 508 p.

StatSoft Inc. 2004. STATISTICA data analysis software system, Version 6.

Vogt, K.A., Grier, C.C., Vogt, D.J. 1986. Production, turnover, and nutrient dynamics of above- and below-ground detritus of world forests. Adv. Ecol. Res. 15, 303-377.

Wang, L.J., Zhang, Y.Q., Ding, Z.L., Xu, X.N. 2010. Foliar nutrient dynamics and nutrient use efficiency of four dominant tree species in a subtropical evergreen broad-leaved forest in Xiaokeng, Southern Anhui. J. Northeast Forestry Univ. 38 , 7 10-12.

Yamashita, T., Kasuya, N., Nishimura, S., Takeda, H. 2004. Comparison of two coniferous plantations in central Japan with respect to forest productivity, growth phenology and soil nitrogen dynamics. For. Ecol. Manage. 200, 215-226.

Zhang, K., Xu, X. N., Wang, Q., Liu, B. 2010a. Biomass, Carbon and nitrogen pools in a subtropical evergreen broad-leaved forest in East China. J. of For. Res. 15, 274-282.

Zhang, K., Xu, X.N., Wang, Q. 2010b. Characteristics of $\mathrm{N}$ mineralization in urban soils of Hefei, East China. Pedosphere. 20, 236-244. 